\title{
ANGPT1 Gene
}

National Cancer Institute

\section{Source}

National Cancer Institute. ANGPT1 Gene. NCI Thesaurus. Code C21311.

This gene plays a role in blood vessel maturation and stability. 